\title{
Problems in Holding President and Parliament General Election in Indonesia
}

\author{
Indarja $^{1}$ and Sekar Anggun Gading Pinilih ${ }^{2}$ \\ \{indarja@yahoo.com ${ }^{1}$, sekar.anggun.gp@gmail.com ${ }^{2}$ \} \\ Faculty of Law, Diponegoro University, 50275, Indonesia
}

\begin{abstract}
Constitutional Court decision number 14/PUU-XI/2013 stated that the elections of President and the Parliament would be held simultaneously. This decision applies for elections since 2019. However, there are many problems if elections co-occur. This research aims to analyze problems that may arise in the implementation of the simultaneous elections of President and the Parliament. The type of research is legal research with a normative point of view. The approaches of the research are the statue and conceptual approach. The primary data of this research is secondary data, which consist of primary and secondary legal material. Based on the research, the release of the Constitutional Court's decision about simultaneous elections of President and the Parliament can cause problems, such as the terms of the presidential threshold are no longer relevant to keep in because there is no separation between the President and Parliament general election.

As a consequence, there will be more political parties built by someone ambitious to become a President, so the desire to have a simple party system will be difficult. Besides, the elections will confuse the voters, especially older adults, because many candidates should be chosen, with lower public participation. Ballot papers counting will take longer and more personals. Also, it will need many apparatus to anticipate the conflict. Therefore, the Commission of General Election must prepare seriously, starting from the regulation, implementation, to settlement of conflicts.
\end{abstract}

Keyword: The Elections, Simultaneously, President, The Parliament

\section{Introduction}

Government system indeed shows the relation between executive and legislative[1]. If the domination and concentration are located on legislative, the government system is parliamentary. On the contrary, if the concentration of authority is centered on the executive, the country follows a presidential system. There is also a mixedgovernmentsystembetweenpresidentialandparliamentary.

The parliamentary government system is a government system in which the Parliament has a vital role in ruling the country. Parliamentarygovernmentsystem, according to Jimmy Asshiddiqie, has six general characteristics, they are: (1) cabinet is formed and responsible for the Parliament; (2) cabinet is formed as a unity with collective responsibility under Ministry supervision; (3) cabinet has constitutional right to dismiss the Parliament before their period is ended; (4) every member in cabinet is a member chosen from Parliament; (5) the Head of Government (Prime Minister) is not elected directly by society, but he is chosen from one of the Parliament functionaries; (6) there is a definite separation between the Head of Country and the Head of Government[2]. 
In the parliamentary government system, the member of Parliament is elected directly by the society, whereas the executive position is decided by the Parliament, which means the member of the Parliament also becomes a cabinet member. The regulation of the Head of Government dramatically depends on the Parliament, because the cabinet is formed by the Parliament and responsible for the Parliament. If the Parliament trusts in the cabinet, the cabinet could continue to rule, and vice versa. When the parliament no longer trusts in the cabinet, the Parliament could dismiss the cabinet and the Prime Minister. Meanwhile, the Head of Country is held by a King or a Queen, if the country is a monarchy, where it is selected from generation to generation. In a monarchy country, the Head of the Government is held by the President elected directly by society regularly during its period, which is limitedintocertaintime.Gerring et al. stated that the parliamentary system had stronger political parties, morecentralizedandparty-alignedinterestgroups, a more centralized decision-making process, andmorecentralizedandhierarchicaladministrativestructures[3].

In the concept of the presidential government system, what is essential is that the position between the executive and the legislative department is the same in strength. For further explanation, the followings are the characteristics of a presidential government system, according to Scott Mainwaring [4]:

1. The president is the Head of Country together with Government;

2. The society elects the president and legislative department;

3. The executive department is not a part of legislative, so it cannot be dismissed by legislative except through impeachment mechanism;

4. President cannot dismiss parliament department.

The implementation of presidential government system could be different in many countries, as some countries apply presidential government system which is combined with two parties system, while others apply presidential government system which is combined with the multi-parties system. What is needed to be understood is multi-parties system is included as a political structure, while the presidential government system is the constitutional structure. Both structures place the same position and strength. The main implication of applying multi-parties system is that the level of party organization is a low and political power in the parliament tends to be fragmented. Fragmentation in politic is hard to avoid in the multi-parties system, which is pluralistic. The position in parliament tends to be distributed evenly, which makes it challenging to have the majority inside.

As a consequence, parties have to form a coalition, either in the government (cabinet) or Parliament. On the other hand, there are an administrative department, personality, and the President's ruling style. Political structure (multi-parties system) and constitutional structure (presidential government system) will influence the style and behavior of presidential institution and personality and vice versa. Ideally, to maintain government stability in presidential political structure, the president's party should be the majority, which is the party supported by the majority of votes in the Parliament. This majority is needed in the Parliament to guarantee the government stability of the elected President so that the President quickly gets political support in the Parliament in order to release policies made by the President. However, these majority votes are difficult to gain by the President's party in the multi-parties situation, except it depends on political parties' coalition in Parliament and cabinet to get the majority votes to maintain the stability of the government.

Indonesia Constitution has confirmed through its characteristics that it follows presidential government system, but this system is applied in the construction of multiparties politic. Multi-parties system is a political context which is hard to avoid because Indonesia has a high level of diversity in society and a high level of complex social 
plurality. Theoretically, the presidential system becomes a problem if it is combined with the multi-parties system. The unstable government in presidential government system is believed to appear more transparent if it is combined with the multi-parties system. Many countries can make a stable government because they combine a presidential government system with a two-party system, not a multi-parties system, for example, the United States.

This presidential government system is the reason why the general election system in Indonesia becomes incompatible and harmonious. Applying presidential in the context of pragmatic multi-parties tends to show a political party's intervention towards the president. On the contrary, the president tends to accommodate the political party's behalf in arranging the cabinet. Forming the cabinet is a prerogative right of President. However, in this multiparties presidential government system, the President involves political parties in making the decision.

The implication of this intervention and accommodation makes the coalition of supportive government becomes fragile. The fragility of coalition bond is generally because political parties in the multi-parties system do not have proximity in ideology, and the composition of parties doing coalition tends to change. Basic presidential system principle like assigning and dismissing cabinet is a prerogative right of the president. In the presidential cabinet, the position of President is a center of executive power. In this regulatory structure, the prerogative right will be reduced. The reduction of President government will be stronger if the formed coalition does not have proximity ideologically or it is pragmatic. Besides, in a presidential system, a coalition among parties also tends to be challenging to form, compared in parliamentary. Remembering that the power of the majority in parties does not exist, there will be a possibility of an impasse in the relationship between legislative and executive, which until now there is no solution to solve.

The President will tend to focus on how to divide cabinet allocation and other political positions as compensation for them who has supported in the Parliament[4]. Besides that, Article 6A paragraph 2the amendment of the 1945 Constitution of Republic of Indonesia (Constitution of Indonesia) also regulated: "the candidates of President and Vice President are proposed by political party or the combination of political parties joining general elections before its enforcement", so it places political parties in every vital position although, in the end, it is the society who elect the President and Vice President. It makes the effectiveness to run a government by President is depended on two things, political support in the Parliament and the society. As a result, the candidates of President and Vice President are "forced" to negotiate and bargain with the police party which has proposed them. It makes the execution of government by President is influenced by the politic parties in Parliament.

The election could produce a divided government, a separated government. It means that legislative is dominated by one or more parties which are different from the party holding executive authority. However, according to Jose Antonio Cheibub, "divided government is not something that will certainly occur in presidential government. Divided government will happen in the countries applying presidential government if: (a) the amount of politic parties is too many (extreme pluralism parties system or atomistic parties); (b) President and Parliament election is not held together, and (c) not applying majoritarian election system, but using proportional election system to choose themember in Parliament".

Completing the presidential system needs to review to the format of candidates system, election scheme and system, and party system. In the context of an election, the regulation 
is not only related to the urgency to change the election system, especially legislative one, but also election scheme to simultaneously election between the legislative election and the presidential election. This regulation points on two schemes of election, national simultaneous election (to elect President/Vice President, Parliament and regional Parliament leader), and regional simultaneous election (to elect regional Parliament and regional leaders, regencies/cities or province), especially after releasing the verdict of the Constitutional Court decision number 14/PUU-XI/2013 on material study of Law Number 42 of 2008 on General Election of President and Vice President. The purpose of this research is to analyze the problems that may occur during the simultaneously general election of President and Parliament.

\section{Methodology}

Thisresearchisnormative juridical approach. The data used are secondary data, which consist of primary law and secondary law materials. In its relation to normative research, the writer uses two approaches; they are statute approach and conceptual approach. Statute approach is an approach done towards many laws related to election and other organic law, which has a relation with the object of the study. Conceptualapproachisusedto understands the concepts of democracy. Imenda said that conceptualortheoreticalframeworkisthesoulofeveryresearchproject[5]. The data ofthis research through studying those documents are then analyzed by using content analysis method. All data that were gathered are done through inventory and systematization, which correlation to the problem being studied is later analyzed.

\section{Literature Review}

Simultaneous elections (concurrent election) could be defined as an election system that performs several elections together in one time. The kinds of those elections include executive and legislative elections in various levels known in the particular country, in national, regional, and local level. In the countries of Europe Union, simultaneous elections even include supra-national, regional, or local level. With the existence of many factors influencing simultaneous elections, there are some variants that some of them have been applied, and the rests are still hypothetic.

Simultaneous election system has been applied in many democratic countries. This system is found not only in the nations who have long enough implemented democracy system like the United States and nations in the area of western Europe but also in many countries which are considered relatively new like nations in the area of Latin America and Eastern Europe. However, in Southeast Asia, a simultaneous election system has not been known for a long time. From five nations who implement election-although, not all democratic-only Philippines who applies simultaneous election system to choose the president and vice president together with legislative members, while Indonesia, Malaysia, Singapore, and Thailand do not use that system[6].

General simultaneous elections are said to be the practice of elections in the history of Indonesia's democracy that has never been done. This urge crystallizes in national politics since the Constitution of Indonesia until now, including the elections after the reformation era. Theoretically, it is possible especially if we see the dynamics of modern politics view and original intent. The general election is only an instrument, and it can be provided based 
on constitutional principles and the policy of a specific country. So, a method could be kept or changed, considering that it is the right democracy view in a specific condition.

The concept of indirect election is known as an effort to strengthen government system. This government system, which is in the interpretation of indirect election, bases on two political legitimations. First, society legimitation has to reach $59 \%+1$ voice nationally and the least of $20 \%$ voices in more than half provinces spreasing in Indonesia. Second, political party legitimation has a position in the parliament. A candidate of the president has to be supported by at least $25 \%$ members in the parliament or $20 \%$ voices nationally. So principally, the divided election is to guarantee that a chosen candidate of the president has support from legislative.

The foundation of this view has passed its importance period because many reasons brought from it are not proven (at least in two periods of election: 2004 and 2009). So indeed, the real motive of indirect election system has lostitsfoundation. Hirano \& Ting stated that under indirect election, the first-stage selectorate was effectively the candidate's combined party caucus in the state legislature since external devices (e.g., direct primaries and nominating conventions) did not formally bind subsequent legislative action [7].

On the other hand, with the change of constitution, it has confirmed the position of President as the head of the government which could no longer to be dismissed by the Parliament due to political reasons. In the context of presidential impeachment, which is Constitution Court, the President could not be dismissed although he/she does not have political support in the parliament.

Irman Putra Sidin emphasized that "the reason or motive of law used to decide the simultaneous elections cannot be kept." So, it needs to purify the constitution. By purifying, the constitution could be a democratic election in which imperative, executive and legislative elections are held together. In the end, constitutional principles which are contained in the norm Article 22E Constitution of Indonesia could be realized correctly[8].

\section{Findings}

4.1. The Urgency of Holding Simultaneous Elections According to Constitutional Court Decision Number14/PUU-XI/2013 on Material Study of Law Number 42 of 2008 on General Election of President and Vice President

General simultaneous elections are said to be the practice of elections in the history of Indonesia's democracy that has never been done. Lastly, the Constitution Court, as a constitutional review of law towards the Constitution of Indonesia, cuts the material review proposal from petitioner. Based on the research, Referring to the law document which is Constitutional Court decision number 14/PUU-XI/2013 that becomes one consideration of petitioner based on Action-Research framework of petitioner which finally concludes that factors significantly obstructing the development of holding elections in Indonesia until today are:

First, transactional politic occurs in layers, generally between political parties and individuals intending to be Public Functionary, and between Politic Parties in positioning certain Public Functionary. Related to the general elections of Legislative Member and the general elecions of President and Vice President, transactional politics could be happen in 4 to 5 period of times, they are: a) during proposing the candidates of legislative members, b) during proposing the candidates of President and Vice President because of Presidential Threshold, c) after knowing the first result of presidential elections (if the second round is needed), d) during cabinet formation, e) during forming a coalition in the Parliament which 
then becomes a prototype to regional parliaments (level I and II), for example the allocation of positions and others.

Second, the cost of politic is very high, redundant, and not done transparently and honestly by the performer or donator. Also, it cannot be supervised adequately by the institution that has authority to do so; including promotion/publication cost and campaign cost that are so excessive (the Minister of Home Affairs Gamawan Fauzi stated that to hold election campaign, the governor of East Java has cost about IDR $1 \mathrm{~T}$ during "ILC" event of TV One Birth, 14 February 2013).

Third, money politics is spreading, as the result of transactional politic among political elites and the candidates of public functionaries, not to mention the administrative cost which is incredibly expensive, and finally continuously to legalize instant strategy like "buying a public vote." On the other hand, those who saw it as an opportunity by some public to involve using money politics, either to join many campaign events and public image or to offer their candidates in a particular general election.

Forth, political corruption which shows the phenomenon of financing Political Parties is connected to the comission from Ministry Project Budget and Departments which are usually discussed/decided in Department Regional Parliament Budget. Meanwhile, executive functionaries are covering the high cost to get a "ticket" or "ship" following elections. Also, the cost of public image and campaign becomes expensive, by allocating many projects in the region, especially natural resources, as a practice of returning the favors to donators or other corruptive practices. The statement of Cross-Religion Pioneer also emphasizes it on September 2012 who said and connected political corruption as a result of general election happening now.

Fifth, The real presidential system is not held correctly or firmly. There are some principles in presidential government system, they are: 1) the Head of Country becomes the Head of Government (executive); 2) the government does not take responsibility to Parliament because the Parliament and the government are in the same level; 3) ministers are chosen and held responsible to the President; 4) executive and legislative are equally healthy. The government system of Indonesia Republic based on the Constitution of Indonesia is presidential. Some of essential characteristics of presidential system are: The President has the authority of government according to the Constitution of Indonesia (article 4 paragraph 1); President and Vice President are elected directly by the society (article 6A paragraph1); their period is specific (article 7); President and Vice President are not responsible in the Parliament (but directly responsible to the people); in its relation to the Parliament, President does not follow the Parliament; and there is no difference in functioning as the Head of Country and government.

\subsection{The Problems that may Arise during Simultaneous President and Parliament Elections in 2019}

Indonesia has held election many times for the Head of Country; in this case, it is a President. Indonesia, which does not use the presidential system had used other system, which was parliamentary, in 1945-1949 during the 1949 Federal Constitution of the United States of Indonesia and 1950-1959 during the Provisional Constitution of 1950. In the first period especially a few years after independence until 2014 positioning legislative and executive is done separately in which legislative election comes first then continued to the presidential election, except after independence when the President and Vice President were chosen by the Committee Preparation of the Independence of Indonesia. After the 
decision of Constitutional Court number 14/PUU-XI/2013, the election in 2019 will be done simultaneously, either in legislative or executive.

Many experts claim that simultaneous elections will bring positive effects to democracy regulation in Indonesia, like the efficiency of election budget, creating the result of the election which is congruent, minimizing conflict among parties, and many others. The Constitution Court even states that the norm of doing president election that is done after legislative election is indeed not in accordance with the meaning of general election in Constitution of Indonesia, especially in article 22E paragraph 1 which stated "The election is held directly, generally, freely, secretly, honestly and fairly every five years" and article 22E paragraph 2 which said, "General election is held to choose the members in the Parliament, Regional Representatives Department, President and Vice President, and regional Parliament", and also article 1 paragraph 2 that said, "The sovereignty is under the people's hands, and it will be organized in accordance with the Constitution". Those mean that indirect election, as proposed by presidential decree, takes issue with the Constitution of Indonesia. However, Constitutional Court considers that holding the election of President and Parliament in 2009 and 2014 which were held indirectly, with all the law effect within, had to be stated as legal and constitutional.

However, this simultaneous national election, according to the writer, also spares some problems as follow:

4.2.1. The problem in determining limitation. The determination of limitation in simultaneous elections becomes polemic. Some suggest that the limitation in becoming the candidates of the president and vice president in the simultaneous election is no longer relevant to be done, remembering that there is no separation between legislative and presidential election. As a result, there will be more parties formed by some figures who have ambition in becoming president. It will bring Indonesia far from the simple party system.

Article 6A Constitution of Indonesia does not state limitation (presidential threshold) in President and Vice President election. It only mentions "the pair of candidates of President and Vice President are proposed by the political party or the association of many parties joining the simultaneous election"[8]. Based on this statement, a political party legally becoming the participants of the simultaneous election has a right to propose its candidates of President and Vice President without fulfilling the limited requirements.

However, some experts say the opposite. By deciding limitation, the chosen President may come from a small party which only has a few parliamentary chairs or even not at the Parliament. As a consequence, government stability decreases because the President is unable to get support from the Parliament. Besides, if the limitation will still be enacted in simultaneous elections, it will limit the people's right to elect as what they expect, and finally, the number of people abstain from voting will possibly increase because there is no one representing their voices. Besides, with limitation, there is a big possibility that there is going to be fewer candidates in the regional.Christiano stated that parliament as institutionsofthesocietymustpubliclyembodytheequaladvancementofinterests in a waythatcanbeclear in principle[9].

The concern about the existence of limitation is better submitted to the former law. However, according to the writer the limitation in simultaneous elections should be maintained because if the limitation of political party participants in the election is not decided, they will face uncontrollable situation because they have to propose so many candidates of President and Vice President. As a result, they are not selective in proposing 
those candidates. They will act practically and pragmatically by choosing the candidates who have an excellent opportunity to win and sell the document of candidacy to whoever pays the highest. In this situation, it is scarce that political parties will support those candidates. They possibly do not pay attention to the quality of their candidates.

4.2.2. I am confusing society. Simultaneous elections could confuse the society, especially the elderly, because there are so many ballot papers to vote, with a possibility of lower society participation. Dealing with the level of human knowledge about the election, Andersen found that simultaneous elections have a negative influence on the knowledge of the candidates the society will elect. There is a limit for an individual's ability to search or understand each needed information to make the right choice in every kind of election. As a result, society will tend to make a priority during the election. According to longitudinal data for 20 years in the US, found that the society will tend to focus on a higher level (national) compared to the candidates on the lower level (countrysides) if both elections are held at the same time.

4.2.3. Difficulty in technical preparation (voting papers, logistics, and others).Simultaneous elections will undoubtedly make the papers thick because many candidates will be elected so that it will affect the complicated preparation of logistics.

4.2.4. It needs more time and energy to count the vote. The process of counting votes needs a long time and costs much energy, so online counting needs to be prepared to make the counting process easier.

4.2.5. Difficulty in supervising and safety. Safety by official seems lacking because of the lack of personals as a consequence if the elections are held in one day. It needs many police or armies to anticipate the possibility of conflict happening. So, the Commission of General Election as the holders has to prepare everything, from making rules, executing, and finishing conflict.

\section{Conclusion}

Holding simultaneous elections may bring advantages and disadvantages. Many experts say that simultaneous elections will bring good effect for the regulation of democracy in Indonesia, like the efficiency of election budget, creating the result of the election which is congruent, minimizing conflict among parties, and many others. However, according to the writer, there are some problems that will occur as a result of holding simultaneous elections of President and Vice President in 2019, for instance; limitation, creating confusion to the society, difficulty in technical preparation especially logistics, costing much time and energy during counting votes, and difficulty in supervising and ensuring safety. Despite those disadvantages, the essential thing that needs to be prepared by the Commission of General Election as the holder of election is preparing the regulation that will be a guideline for election, implementing the process, and solving the conflict of the election result. 


\section{References}

[1] R. Sihbudi and M. Nurhasim, Amandemen Konstitusi dan Strategi. Jakarta, 2002.

[2] J. Asshiddiqie, Pergumulan Peran Pemerintah dan Parlemen Dalam Sejarah: Telaah Perbandingan Konstitusi Berbagai Negara. Jakarta: UII Press, 1996.

[3] J. Gerring, S. C. Thacker, and C. Moreno, "Are Parliamentary Systems Better?," Comp. Polit. Stud., vol. 42, no. 3, pp. 327-359, 2008.

[4] R. Saraswati, "Desain Sistem Pemerintahan Presidential Yang Efektif," Masal. Huk., vol. 41 , no. 1, p. 138.

[5] S. Imenda, "Is There a Conceptual Difference between Theoretical and Conceptual Frameworks?," J. Soc. Sci., vol. 38, no. 2, pp. 185-195, 2014.

[6] S. D. Haris, Pemilu Nasional Serentak 2019. Jakarta, 2014

[7] S. Hirano and M. M. Ting, "Direct and indirect representation," Br. J. Polit. Sci., vol. 45, no. 3, pp. 609-634, 2014.

[8] S. Sodikin, "No Title," J. Rechts ind ing Jur l Rechtsind, vol. 3, pp. 19-31, 2014.

[9] T. Christiano, "The Authority of Democracy," J. Polit. Philos., vol. 12, no. 3, pp. 266-290, 2004. 